\title{
Wsparcie instytucji finansowych przez Skarb Państwa w dobie kryzysu finansów publicznych
}

\section{Wstęp}

Ostatni kryzys finansowy rozpoczął się latem 2007 r. od zapaści na amerykańskim rynku pożyczek hipotecznych. Początkowo miał on niewielki wpływ na polski system finansowy, który sprowadzał się niemal wyłącznie do spadku cen akcji na Giełdzie Papierów Wartościowych ${ }^{1}$. Sytuacja ta zmieniła się we wrześniu 2008 r. po upadku amerykańskiego banku inwestycyjnego Lehman Brothers. Wydarzenia na globalnym rynku finansowym doprowadziły w Polsce do spadku wzajemnego zaufania banków, a tym samym do obniżenia płynności krajowego rynku międzybankowego ${ }^{2}$. Przyczyną takiego stanu rzeczy był przede wszystkim wzrost ryzyka kredytowego kontrahenta, wynikający z niepewności co do sytuacji finansowej inwestorów strategicznych banków krajowych ${ }^{3}$. Spadek płynności na rynku międzybankowym i związane z tym negatywne konsekwencje dla sfery realnej gospodarki skłoniły polskie władze monetarne i fiskalne do podjęcia kroków zaradczych. W przypadku NBP zostały one ujęte w ramach tzw. pakietu zaufania, obejmującego działania zmierzające do zwiększenia możliwości pozyskiwania przez banki środków złotowych i walutowych ${ }^{4}$. Władze fiskalne wystąpiły natomiast z tzw. pakietem regulacyjnym, obejmującym projekt: ustawy o Komitecie Stabilności Finansowej, ustawy zmieniającej ustawę o Bankowym Funduszu Gwarancyjnym $^{5}$ oraz ustawy o udzielaniu przez Skarb Państwa wsparcia instytu-

* Dr Przemysław Panfil - Katedra Prawa Finansowego, Wydział Prawa i Administracji, Uniwersytet Gdański.

${ }^{1}$ Raport o stabilności systemu finansowego - czerwiec 2008 r., NBP, Warszawa 2008, s. 7.

2 Raport o stabilności systemu finansowego - październik 2008 r., NBP, Warszawa 2008, s. 7.

${ }_{3}^{3}$ M. Konopczak, R. Sieradzki, M. Wiernicki, Kryzys na światowych rynkach finansowych - wplyw na rynek finansowy w Polsce oraz implikacje dla sektora realnego, „Bank i Kredyt” 2010, nr 6, s. 59.

${ }^{4}$ Raport o stabilności systemu finansowego - październik..., s. 11-12.

${ }_{5}$ Zmiana ta miała na celu przede wszystkim zwiększenie poziomu ochrony depozytów z równowartości 22,5 tys. euro do 50 tys. euro. 
cjom finansowym (dalej: u.w.i.f.). Ta ostatnia ustawa została ostatecznie uchwalona 12 lutego 2009 r. Początkowo miała obowiązywać do końca 2009 r., z czasem nadano jej jednak charakter bezterminowy. Co ciekawe, przepisy u.w.i.f., zgodnie z oczekiwaniami jej projektodawcy, nie znalazły dotychczas praktycznego zastosowania. Niemniej sama możliwość uzyskania przez instytucję finansową wsparcia od Skarbu Państwa zdaje się odbudowywać zaufanie między uczestnikami rynku finansowego, a tym samym podnosić jego płynność. Zasadnym wydaje się jednak próba odpowiedzi na pytanie, jakie są rzeczywiste możliwości ingerowania państwa w procesy zachodzące na tym rynku, szczególnie w kontekście rosnącego poziomu zadłużenia publicznego. Odpowiedź na to pytanie wymaga bliższej analizy przepisów u.w.i.f. oraz oceny wpływu przewidzianych w niej form wsparcia instytucji finansowych na sytuację budżetu państwa.

\section{Zakres podmiotowy i cel wsparcia instytucji finansowych}

Z punktu widzenia ewentualnych konsekwencji, jakie dla budżetu państwa może rodzić wsparcie Skarbu Państwa dla instytucji finansowych, istotne znaczenie ma zarówno katalog instytucji, które mogą takie wsparcie uzyskać, jak i cel, którego realizacji wsparcie to ma służyć. Zakres podmiotowy omawianych regulacji określa art. 2 u.w.i.f. W przepisie tym ustawodawca umieścił katalog instytucji finansowych, które mogą otrzymywać wsparcie ze strony Skarbu Państwa. Obejmuje on:

- banki krajowe;

- spółdzielcze kasy oszczędnościowo-kredytowe;

- Krajową Spółdzielczą Kasę Oszczędnościowo-Kredytową;

- fundusze inwestycyjne;

- domy maklerskie;

- krajowe zakłady ubezpieczeń;

- fundusze emerytalne.

Powyższy katalog sprawia, że regulacje zawarte w omawianej ustawie mają de facto charakter sektorowy. Wsparcie Skarbu Państwa nie ogranicza się wyłącznie do podmiotów rynku międzybankowego, ale dedykowane jest wszystkim najważniejszym instytucjom finansowym, tworzącym jedno z ogniw krajowego systemu finansowego. Takie podejście ustawodawcy wpisuje się w schemat działań podejmowanych $\mathrm{w}$ trakcie ostatniego kryzysu $\mathrm{w}$ krajach wysoko rozwiniętych. W wielu z nich miały one bardzo szeroki zakres podmiotowy i obejmowały nie tylko banki, ale także inne instytucje finansowe, a niekiedy nawet podmioty sfery realnej gospodarki ${ }^{6}$.

${ }^{6}$ N. Roubini, S. Mihm, Ekonomia kryzysu, Warszawa 2011, s. 181-182, 194-199. 
Cel, którego realizacji służy wsparcie Skarbu Państwa dla instytucji finansowych, został wyartykułowany w art. 1 u.w.i.f. Jest nim utrzymanie płynności płatniczej tych instytucji, co powinno przyczynić się do rozwoju akcji kredytowej banków krajowych, a tym samym do ograniczenia negatywnego wpływu zaburzeń występujących na rynku finansowym na sferę realną gospodarki. Należy podkreślić, że polskie rozwiązania, w odróżnieniu od działań podejmowanych w wielu państwach wysoko rozwiniętych, nie zmierzają do ratowania podmiotów niewypłacalnych? ${ }^{7}$.

\section{Wsparcie instytucji finansowych za pomocą gwarancji Skarbu Państwa}

Wśród form wsparcia instytucji finansowych, które zostały wymienione w art. 3 ust. 1 u.w.i.f. znalazły się gwarancje Skarbu Państwa. Występują one w dwóch odmianach: gwarancji dla NBP i gwarancji za instytucję finansową. Ta pierwsza stanowi zabezpieczenie wierzytelności banku centralnego z tytułu udzielonego bankowi krajowemu kredytu refinansowego. Zgodnie z art. 42 ust. 1 ustawy z dnia 29 sierpnia 1997 r. o NBP ${ }^{8}$ kredyty te udzielane są w złotych w celu uzupełnienia zasobów pieniężnych banków. Bank centralny kieruje się przy tym zdolnością kredytobiorcy do spłaty zaciągniętych zobowiązań. Gwarancja dla NBP zwiększa więc szanse banku krajowego na otrzymanie kredytu refinansowego. Rozwiązanie to koresponduje $\mathrm{z}$ działaniami podjętymi przez bank centralny w ramach $\mathrm{Pa}-$ kietu zaufania. Polegały one m.in. na wprowadzeniu depozytu walutowego jako zabezpieczenia kredytu refinansowego oraz zwiększenia listy aktywów mogących stanowić zabezpieczenie dla kredytu lombardowego, czyli jednej z form refinansowania stosowanej przez bank centralny ${ }^{9}$.

Gwarancja za instytucję finansową stanowi formę zabezpieczenia spłaty kredytu lub linii kredytowej udzielonej bankowi krajowemu, Krajowej Spółdzielczej Kasie Oszczędnościowo-Kredytowej lub spółdzielczej kasie oszczędnościowo-kredytowej ${ }^{10}$. W dwóch pierwszych przypadkach kredytodawcą może być bank krajowy, bank zagraniczny lub instytucja kredytowa, w ostatnim - Krajowa Spółdzielcza Kasa Oszczędnościowo-Kredytowa. Gwarancją za instytucję finansową mogą być przy tym objęte tylko te zobowiązania, które są zaciągane w celu utrzymania odpowiedniego poziomu płynności. Dodatkowo należy podkreślić, że po-

7 Ibidem, s. 140.

${ }^{8}$ T.j. Dz. U. z 2005 r. Nr 1, poz. 2 ze zm.

${ }_{9}^{9}$ Raport o stabilności systemu finansowego-październik..., s. 12.

${ }^{10} \mathrm{Z}$ tej formy wsparcia mogą więc skorzystać tylko nieliczne instytucje finansowe wymienione w art. 2 u.w.i.f. W tym kontekście za nieadekwatną należy uznać zastosowaną przez ustawodawcę nazwę ,gwarancja za instytucję finansową". 
jęcie „kredyt” w rozumieniu u.w.i.f. obejmuje także emisję lub wystawienie przez bank krajowy, spółdzielczą kasę oszczędnościowo-kredytową lub Krajową Spółdzielczą Kasę Oszczędnościowo-Kredytową dłużnych papierów wartościowych. Skarb Państwa może jednak gwarantować spełnienie przez emitenta świadczeń pieniężnych wynikających $\mathrm{z}$ tych papierów tylko wtedy, jeżeli zostały one wyemitowane $\mathrm{z}$ terminem zapadalności nie krótszym niż 3 miesiące i nie dłuższym niż 5 lat.

Gwarancja dla NBP i gwarancja za instytucję finansową obejmuje spłatę kredytu wraz z odsetkami umownymi oraz innymi związanymi z nim kosztami. Gwarancje te nie mogą jednak obejmować zobowiązań, których zabezpieczenie stanowią skarbowe papiery wartościowe oraz papiery wartościowe wyemitowane przez NBP - do wysokości ich wartości nominalnej. W tym wypadku spłata kredytu jest już, przynajmniej z ekonomicznego punktu widzenia, gwarantowana przez Skarb Państwa lub bank centralny. Ustawodawca nie wprowadza dodatkowych ograniczeń w zakresie gwarancji za instytucję finansową. Natomiast gwarancja dla NBP jest limitowana do 50\% pozostającej do spłaty kwoty kredytu refinansowego.

Zgodnie z art. 216 ust. 4 Konstytucji udzielanie poręczeń i gwarancji finansowych przez państwo następuje na zasadach i w trybie określonym w ustawie. Dyspozycja ta jest wypełniana przede wszystkim przez ustawę z dnia 8 maja $1997 \mathrm{r}$. o poręczeniach i gwarancjach udzielanych przez Skarb Państwa oraz niektóre osoby prawne ${ }^{11}$ (dalej: u.p.g). Akt ten zawiera szereg rozwiązań, które minimalizują ryzyko związane z tym aspektem działalności państwa. W polskim systemie prawnym funkcjonuje także kilka ustaw mających charakter lex specialis $\mathrm{w}$ stosunku do u.p.g. Na ich podstawie Skarb Państwa może stosować poręczenia i gwarancje w celu wsparcia ściśle określonych zadań lub rodzajów działalności, co pozwala określić je mianem ustaw sektorowych. Akty te w mniejszym lub większym stopniu rozluźniają reżim prawny wynikający z u.p.g., przyczyniając się tym samym do wzrostu ryzyka związanego z udzielanymi zabezpieczeniami. Niewątpliwie do tego typu ustaw należy zaliczyć u.w.i.f. Zgodnie z zawartymi w niej regulacjami do gwarancji dla NBP i gwarancji za instytucje finansowe stosuje się jedynie art. 31 u.p.g. Przepis ten stanowi, że łączna kwota, do wysokości której mogą być udzielane przez Skarb Państwa poręczenia i gwarancje, określa ustawa budżetowa. Co ciekawe, ustawodawca wyłączył stosowanie limitu określonego w tej ustawie w przypadku skarbowych papierów wartościowych, czyli drugiego instrumentu wykorzystywanego do wsparcia instytucji finansowych. Dywersyfikacja ta ma racjonalne uzasadnienie. Emisja skarbowych papierów wartościowych prowadzi do wzrostu państwowego długu publicznego, co w kontekście obowiązującego limitu zadłużenia ogranicza zastosowanie tego instrumentu. Skutków takich nie rodzi udzielenie gwarancji Skarbu Państwa, które nie powoduje natychmiastowego

${ }_{11}$ T.j. Dz. U. z 2003 r. Nr 174, poz. 1689 ze zm. 
zaangażowania środków publicznych ${ }^{12}$. Przyczynia się natomiast do wzrostu tzw. długu potencjalnego, ewidencjonowanego jako kwota ryzyka zaciągnięta na rachunek państwa, a w konsekwencji podatników. Dokładnie nie wiadomo, jaka część długu potencjalnego przekształci się w dług zapadalny i będzie skutkować wypłatą z zasobów budżetowych ${ }^{13}$. Ewentualna niewypłacalność dłużników podstawowych spowoduje skokowy wzrost państwowego długu publicznego, co może prowadzić do naruszenia konstytucyjnego limitu zadłużenia, czy też obniżenia wiarygodności kredytowej Polski. Wydaje się jednak, że norma wyrażona w art. 31 u.p.g. nie stanowi wystarczającego zabezpieczenia przed powyższym ryzykiem. Dotychczas Sejm uchwalał wspomniany limit na poziomie zaproponowanym w projekcie ustawy budżetowej przez Radę Ministrów ${ }^{14}$. Był on przy tym na tyle wysoki, że nawet potencjalnie nie stanowił ograniczenia dla procesu udzielania poręczeń i gwarancji przez Skarb Państwa ${ }^{15}$. W związku z tym jedyną przeszkodą w wykorzystaniu tego instrumentu okazuje się reguła fiskalna zawarta w art. 86 ust. 1 pkt 3 lit. d ustawy z dnia 27 sierpnia 2009 r. o finansach publicznych $^{16}$ (dalej: u.f.p.). Wprowadza ona zakaz udzielania poręczeń i gwarancji przez jednostki sektora finansów publicznych, gdy państwowy dług publiczny osiągnie poziom $60 \%$ PKB.

\section{Wsparcie instytucji finansowych przy pomocy skarbowych papierów wartościowych}

Do wsparcia instytucji finansowych władze fiskalne mogą także wykorzystywać skarbowe papiery wartościowe. Są one przekazywane tym instytucjom w drodze:

- pożyczki;

- sprzedaży z odroczonym terminem płatności;

- sprzedaży z rozłożeniem płatności na raty;

- sprzedaży w drodze oferty kierowanej do określonej instytucji finansowej.

Instytucje finansowe mogą wykorzystywać otrzymane skarbowe papiery wartościowe chociażby jako formę zabezpieczenia spłaty zaciąganych zobowią-

${ }_{12}$ P. Panfil, Poręczenia i gwarancje Skarbu Państwa, [w:] A. Drwiłło, D. Maśniak (red.), Leksykon prawa finansowego - 100 podstawowych pojęć, Warszawa 2009, s. 322.

13 R. Klocek, Poręczenia i gwarancje Skarbu Państwa - stabilne zabezpieczenia finansowe. Komentarz, Warszawa 2000, s. IX.

${ }_{14}$ P. Panfil, Prawne i finansowe uwarunkowania dtugu Skarbu Państwa, Warszawa 2011, s. $325-326$.

15 Przykładowo, w ustawie budżetowej na rok 2012 z dnia 2 marca 2012 r. (Dz. U. z 2012 r., poz. 273) limit ten ustalono na poziomie aż $200 \mathrm{mld} z ł$.

16 Dz. U. z 2009 r. Nr 157, poz. 1240 ze zm. 
zań ${ }^{17}$ lub też do dokonania tzw. sprzedaży krótkiej. W każdym przypadku wsparcie otrzymane ze strony Skarbu Państwa zwiększa zdolność danego podmiotu do skutecznego zasilania się w płynność na rynku finansowym.

Skarbowe papiery wartościowe przekazywane instytucjom finansowym w oparciu o przepisy u.w.i.f. należy zaliczyć do tzw. instrumentów pasywnych. Kategoria ta obejmuje papiery dłużne, których podstawowym celem emisji nie jest finansowanie potrzeb pożyczkowych budżetu państwa. Część z nich nie stanowi nawet źródła przychodów publicznych. Sytuacja taka ma miejsce chociażby w przypadku skarbowych papierów wartościowych, emitowanych jako przedmiot pożyczki dla instytucji finansowych. Niemniej instrumenty pasywne, o ile tylko opiewają na świadczenia pieniężne, należą do tytułów dłużnych zaliczanych w myśl art. 72 ust. 1 u.f.p. do długu Skarbu Państwa i jednocześnie państwowego długu publicznego ${ }^{18}$. W tym kontekście zbędny wydaje się art. 14 ust. 3 u.w.i.f., gdyż powiela regulacje zawarte już w polskim systemie prawnym. Zgodnie z tym przepisem wartość nominalną zobowiązań z tytułu skarbowych papierów wartościowych wyemitowanych w celu wsparcia instytucji finansowych zalicza się do długu Skarbu Państwa. Przesądza on jednak, że papiery emitowane w oparciu o przepisy u.w.i.f. mogą opiewać wyłącznie na świadczenia pieniężne. Tylko bowiem takie instrumenty są zaliczane do długu Skarbu Państwa, który to jest kategorią o charakterze pieniężnym. Do podobnych wniosków można dojść w oparciu o treść art. 12 ust. 2 u.w.i.f., który wśród obligatoryjnych elementów listu emisyjnego, poprzedzającego każdą emisję, wymienia m.in. stopę procentową oraz należność główną i uboczną.

Mechanizm wykorzystania skarbowych papierów wartościowych do udzielania wsparcia instytucjom finansowym cechuje się wysokim poziomem elastyczności. Znacząco upraszcza to i przyśpiesza działania podejmowane w tym zakresie przez ministra finansów. W dużej mierze jest to efektem ograniczenia do minimum regulacji u.w.i.f. dotyczących tego mechanizmu. Dodatkowo, w przypadku skarbowych papierów wartościowych wykorzystywanych do wsparcia instytucji finansowych ustawodawca wyłączył zastosowanie art. 95-97 u.f.p. W konsekwencji minister finansów nie musi określać w drodze rozporządzenia warunków emitowania tych instrumentów. Kwestia ta obok sposobu realizacji świadczeń ze skarbowych papierów wartościowych jest natomiast precyzowana w listach emisyjnych. Są one wydawane na potrzeby poszczególnych emisji przez ministra finansów. Tym samym organ ten może dostosowywać konstrukcję skarbowych papierów wartościowych do konkretnych potrzeb.

Do emisji skarbowych papierów wartościowych w oparciu o przepisy u.w.i.f. dochodzi $\mathrm{z}$ dniem zarejestrowania tych instrumentów w depozycie papierów

17 Przykładowo, dla banków krajowych mogą to być zobowiązania wynikające z kredytu lombardowego.

${ }^{18}$ Pod warunkiem jednak, że papierów takich nie nabyła inna jednostka sektora finansów publicznych. 
wartościowych oraz w kwocie równej ich wartości nominalnej. Automatycznie powoduje to wzrost długu Skarbu Państwa i państwowego długu publicznego. Co szczególnie istotne, w art. 14 ust. 2 u.w.i.f. ustawodawca przesądził, że emisji skarbowych papierów wartościowych przeznaczonych na wsparcie dla instytucji finansowych nie wlicza się do limitów określonych w ustawie budżetowej ${ }^{19}$. $\mathrm{Z}$ punktu widzenia regulacji zawartych $\mathrm{w}$ omawianej ustawie minister finansów ma więc dużą swobodę w zakresie kształtowania wielkości emisji tych instrumentów. Najważniejsze ograniczenie w tym zakresie stanowi sytuacja, w której państwowy dług publiczny zbliża się do wartości $60 \%$ rocznego PKB. Groźba złamania reguły fiskalnej wyrażonej w art. 216 ust. 5 Konstytucji powinna być wystarczającą przesłanką do zakończenia emisji skarbowych papierów wartościowych przeznaczonych na wsparcie dla instytucji finansowych. Należy przy tym pamiętać, że to minister finansów, zgodnie z art. 74 ust. 1 u.f.p., sprawuje kontrolę nad sektorem finansów publicznych w zakresie przestrzegania limitu zadłużenia i ponosi konstytucyjną odpowiedzialność za ewentualne jego przekroczenie. Trudno także spodziewać się, że organ ten zdecyduje się na emisję skarbowych papierów wartościowych przeznaczonych na wsparcie dla instytucji finansowych, jeżeli miałoby to prowadzić do osiągnięcia któregoś z progów wyznaczonych przez procedury ostrożnościowo-sanacyjne. Taka sytuacja miałaby bowiem negatywne konsekwencje dla swobody prowadzenia przez rząd polityki fiskalnej w kolejnych latach.

\section{Zasady i tryb udzielania wsparcia instytucjom finansowym}

Minister finansów, działając w imieniu Skarbu Państwa, udziela wsparcia instytucji finansowej na jej wniosek. W art. 15 ust. 2 u.w.i.f. ustawodawca uregulował obligatoryjne elementy tego wniosku. Jednym $\mathrm{z}$ nich jest informacja o aktualnej sytuacji ekonomiczno-finansowej wnioskodawcy. Pozwala ona oszacować ryzyko, jakie dla Skarbu Państwa niesie udzielenie wsparcia konkretne$\mathrm{mu}$ podmiotowi. Poczynione w tym zakresie ustalenia nie mają jednak prawnie wiążącego charakteru. Oznacza to, że minister finansów może udzielić wsparcia instytucji finansowej, ignorując związane z tym ryzyko. Z jednej strony zwiększa to możliwość podjęcia przez ten organ skutecznej ingerencji w działanie rynku finansowego. $Z$ drugiej staje się poważnym zagrożeniem dla stabilności finansowej Skarbu Państwa i realizacji ustawy budżetowej w kształcie nadanym jej przez parlament. W tym ostatnim wypadku należy zwrócić uwagę na treść art. 18 u.w.i.f.

${ }^{19} \mathrm{Na}$ marginesie należy zauważyć, że art. 14 ust. 2 u.w.i.f. jest de facto zbędny. Ograniczenie wielkości emisji skarbowych papierów wartościowych do limitu określonego w ustawie budżetowej wprowadza bowiem art. 95 ust. 2 u.f.p., którego zastosowanie do instrumentów przeznaczonych na wsparcie dla instytucji finansowych zostało przez ustawodawcę wyłączone. 
Zgodnie z tym przepisem Rada Ministrów, na wniosek ministra finansów, może, po zaciągnięciu opinii komisji sejmowej właściwej do spraw budżetu, w drodze rozporządzenia dokonać przeniesienia planowanych wydatków budżetowych między częściami i działami budżetu państwa w celu realizacji zadań wynikających z omawianej ustawy. W skrajnym przypadku, biorąc pod uwagę nieograniczone de facto prawo kreowania długu Skarbu Państwa w oparciu o u.w.i.f., może to skutkować całkowitą zmianą budżetu przez organ władzy wykonawczej. Konieczność przestrzegania konstytucyjnego limitu zadłużenia nie wydaje się przy tym wystarczającym zabezpieczeniem przed wystąpieniem takiego zdarzenia. Może do niego dojść chociażby za sprawą przekształcenia się wynikającego z udzielonych gwarancji długu potencjalnego w dług rzeczywisty. Kompetencje, jakie ustawodawca nadał ministrowi finansów i Radzie Ministrów, zdają się więc wykraczać poza tradycyjnie określone zadania organów władzy wykonawczej w zakresie procedury budżetowej. Niewiele w tym zakresie zmienia art. 19 u.w.i.f., która nakłada na ministra finansów obowiązek przedstawiania komisji sejmowej właściwej do spraw budżetu kwartalnych informacji o podejmowanych działaniach będących realizacją postanowień tej ustawy. Przed udzieleniem wsparcia instytucji finansowej organ ten musi natomiast zaciągnąć opinię Komisji Nadzoru Finansowego oraz Prezesa NBP, a w przypadku wsparcia udzielonego bankowi - również Bankowego Funduszu Gwarancyjnego. Podmioty te są niewątpliwie predysponowane do dokonania oceny zasadności planowanych działań z punktu widzenia przywracania płynności na rynku finansowym. Poza zakresem ich kompetencji znajduje się jednak analiza sytuacji finansowej Skarbu Państwa.

Wsparcie instytucji finansowej udzielane jest na podstawie umowy zawartej przez nią z ministrem finansów. U.w.i.f. wprowadza przy tym szereg wymogów, których celem jest zabezpieczenie interesów Skarbu Państwa. Za najważniejszy należy uznać, ciążący na instytucji finansowej, obowiązek ustanowienia zabezpieczenia wierzytelności wynikających z udzielonego jej wsparcia. Rozwiązanie to współgra $z$ uprawnieniem ministra finansów do wystawiania tytułów wykonawczych na podstawie dokumentów związanych z tą wierzytelnością. Niewątpliwie regulacje te w dłuższym okresie czasu umożliwiają „odzyskanie” środków publicznych zaangażowanych we wsparcie instytucji finansowych. W krótkim okresie nie stanowią jednak żadnej przeszkody dla skokowego wzrostu długu Skarbu Państwa, spadku wiarygodności kredytowej tego podmiotu, a nawet jego bankructwa.

\section{Podsumowanie}

Spadek płynności na rynku finansowym, a w szczególności na jednym z jego kluczowych segmentów, czyli rynku międzybankowym, rodzi negatywne konsekwencje dla sfery realnej gospodarki i staje się wyzwaniem dla procesu finansowania potrzeb pożyczkowych budżetu państwa. Stanowi to wystarczające 
uzasadnienie dla wprowadzenia do polskiego porządku prawnego regulacji, które normują zasady i tryb udzielania wsparcia instytucjom finansowym przez Skarb Państwa. Stworzenie ram prawnych, na podstawie których państwo może ingerować w procesy zachodzące na rynku finansowym, nie przesądza jeszcze o możliwości przeprowadzenia takiej ingerencji, ani tym bardziej jej skuteczności. Jednym z najważniejszych czynników ograniczających aktywność Skarbu Państwa w tym zakresie jest wpływ podejmowanych działań na poziom państwowego długu publicznego, który zgodnie z konstytucyjną regułą fiskalną nie może przekroczyć $60 \%$ PKB. Tym samym dobry stan finansów publicznych jest niezbędnym warunkiem skutecznego wsparcia instytucji finansowych przez państwo. Wysoki poziom zadłużenia Skarbu Państwa redukuje znaczenie u.w.i.f. wyłącznie do roli psychologicznego czynnika oddziaływania na uczestników rynku finansowego. $Z$ drugiej strony ustawa ta rodzi określone zagrożenia dla stabilności finansów publicznych w Polsce. Nie zawiera bowiem rozwiązań, które stanowiłyby przeszkodę dla nadużywania przez ministra finansów mechanizmów wsparcia instytucji finansowych. Paradoksalnie, największe ryzyko wiąże się z procesem udzielania gwarancji, które nie powodują automatycznie zaangażowania środków publicznych ani też wzrostu państwowego długu publicznego. Może to rodzić błędne przeświadczenie, że instrument ten można wykorzystywać na dowolnie dużą skalę. 